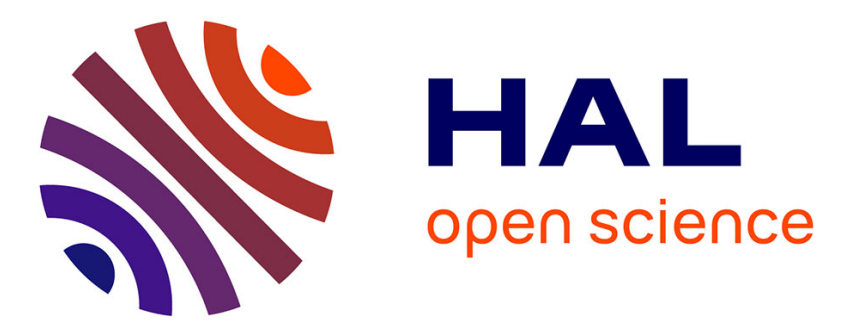

\title{
Development of schistosity by dissolution-crystallization in a Californian serpentinite gouge
}

\author{
Muriel Andréani, Anne-Marie Boullier, Jean-Pierre Gratier
}

\section{To cite this version:}

Muriel Andréani, Anne-Marie Boullier, Jean-Pierre Gratier. Development of schistosity by dissolutioncrystallization in a Californian serpentinite gouge. Journal of Structural Geology, 2005, 27 (12), pp.2256-2267. 10.1016/j.jsg.2005.08.004 . hal-00107199

\section{HAL Id: hal-00107199 \\ https://hal.science/hal-00107199}

Submitted on 21 Jan 2018

HAL is a multi-disciplinary open access archive for the deposit and dissemination of scientific research documents, whether they are published or not. The documents may come from teaching and research institutions in France or abroad, or from public or private research centers.
L'archive ouverte pluridisciplinaire HAL, est destinée au dépôt et à la diffusion de documents scientifiques de niveau recherche, publiés ou non, émanant des établissements d'enseignement et de recherche français ou étrangers, des laboratoires publics ou privés. 


\title{
Development of schistosity by dissolution-crystallization in a Californian serpentinite gouge
}

\author{
M. Andreani*, A.-M. Boullier, J.-P. Gratier \\ LGIT, BP 53, 38041 Grenoble Cedex 9, France
}

\begin{abstract}
To understand the behaviour and deformation mechanisms of serpentinites in the seismogenic zone we study the deformation macro- and microstructures of serpentinites along the Santa Ynez Fault in the San Andreas System. At the outcrop scale, deformation is localized in a gouge zone that shows three different structures: (1) micrometric undeformed fragments (clasts) of the previously serpentinized peridotite, (2) localized shear planes (Y and R) and (3) a penetrative schistosity (S). Observations under SEM and TEM reveal that the schistosity corresponds to serpentine fibres, parallel to each other, and whose orientation varies as they wrap around clasts. TEM micro-textures indicate that these long fibres result from continuous syntectonic growth rather than from reorientation of pre-existing fibres implying a slow transfer process that occurs at short distances. We propose a dissolution-diffusion-crystallization process for the formation of the schistosity that corresponds to a low strain-rate creeping process of deformation that can be effective in aseismic fault segments.
\end{abstract}

Keywords: Serpentines; Gouge; Microstructures; TEM; Pressure-solution creep; Aseismic fault

\section{Introduction}

The distribution of seismic activity along Californian active faults reveals a partitioning between seismic and aseismic or creeping segments (e.g. Allen, 1968; Schulz et al., 1982) (Fig. 1). Serpentinites formed by the hydration of mantle peridotites are present at several locations in California and are particularly common along the creeping segments of the San Andreas Fault system. Experiments on serpentinites reveal that they have a low fracture strength (Raleigh and Paterson, 1965; Escartin et al., 1997) and a low coefficient of friction $(\mu)$, which can be as low as $\mu=0.1$ at room temperature (Reinen et al., 1991; Reinen, 2000). Experiments on wet chrysotile-dominated gouges shows a positive temperature dependence and under certain conditions display velocity strengthening, and therefore a

\footnotetext{
* Corresponding author. Present address. Institut de Physique du Globe, Laboratoire de Geosciences Marines, 4 Place Jussieu, Case 89, 75252 Paris Cedex 5, France. Tel.: +33144 274833; fax: +33144279969.

E-mail address: andreani@ipgp.jussieu.fr (M. Andreani).
}

stabilizing behaviour during deformation (Moore et al., 1996, 1997). Thus, the mechanical behaviour of serpentinites have been proposed to be a potential cause of aseismic creep on some fault segments (San Andreas Fault: Irwin and Barnes, 1975; Hayward Fault: Bürgmann et al., 2000) (Fig. 1). However, no careful study of deformation microstructures (scanning and transmission electron microscopy or SEM and TEM) of these naturally deformed rocks has been undertaken to date so as to characterize the mode of deformation and the relationship between serpentinite formation and deformation.

In order to better understand the deformation mechanisms of serpentinites in the context of the seismogenic zone we have studied the deformation microstructures of serpentines affected by faulting within the San Andreas Fault system (California) at different scales of observation. We present field, optical microscope, SEM and TEM observations of outcrops and deformed rocks. Based on these observations, which range from the nano- to the macroscopic scale, and on our analyses, we propose a model for the formation of the schistosity, and the deformation conditions at which this schistosity formed. In this paper we refer to schistosity as a penetrative structure that accommodates distributed deformation. 


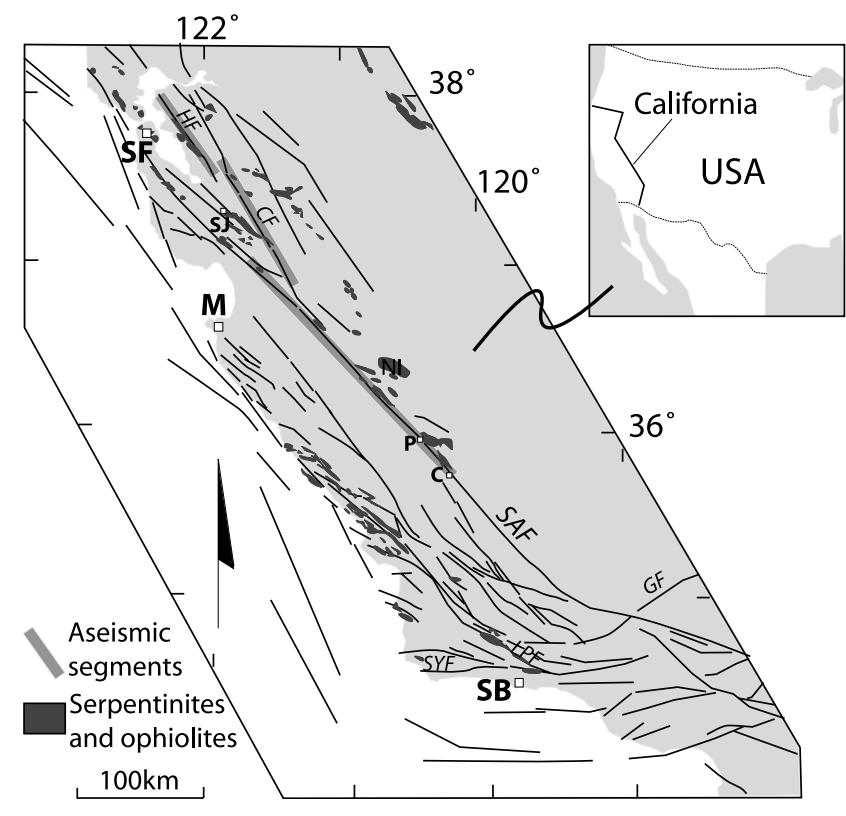

Fig. 1. Distribution of serpentinite outcrops in Central California and localization of major faults with aseismic segments (redrawn after Allen, 1968; Irwin and Barnes, 1975; Page et al., 1998; Coleman, 2000). SF, San Francisco; SB, Santa Barbara; SJ, San Jose; M, Monterey; P, Parkfield; C, Cholame; SAF, San Andreas Fault; HF, Hayward Fault; CF, Calaveras Fault; GF, Garlock Fault; SYF, Santa Ynez Fault; LPF, Little Pine Fault.

\section{Geological setting}

The western coast of North America has undergone different episodes of deformation from the Mesozoic to the Present, marked by the alternation of subduction and transform episodes (Atwater, 1989) resulting in the complex geology along the California coast. Among the various lithologies, kilometre-scale serpentinite units are exposed in different locations along the San Andreas Fault system. These bodies are remnants of Mesozoïc oceanic crust and altered mantle (Bailey et al., 1970; Page, 1972; Page et al., 1998) and are locally crosscut by active faults.

This study focuses on a kilometre-scale serpentinite unit that lies along a segment of the western part of the Santa Ynez fault (SYF on Fig. 1), located north of Santa Barbara. Serpentinites of this region are tectonically associated with rocks of the Franciscan subduction melange. The Santa Ynez fault is known as an active sinistral-reverse fault, with a dominant sinistral component on the studied segment (Fig. 2), and a low displacement rate between 0.1 and $0.7 \mathrm{~mm} / \mathrm{yr}$ (www.data.scec.org). The Blue Canyon offers well-exposed outcrops with scant superficial alteration of the serpentinites affected by this active fault. Detailed descriptions of outcrops of this site are given in the following parts.

\section{Mesoscopic observations}

Along the serpentinite unit, the Santa Ynez fault is divided into two segments (Fig. 2). Fig. 3 illustrates the northern trace of the fault and shows the characteristic structure of the serpentinite unit at the outcrop. This unit is composed of blocks of massive serpentinized peridotites (circled on Fig. 3) separated by a schistose serpentinite where two types of textures were observed. The first one is an anastomosing schistosity that wraps around the massive blocks and has an overall moderate average dip of $45^{\circ}$ to the NNE. By comparison with other studies of ultramafic units in western California (e.g. Page, 1968; Page et al., 1998), this schistosity can be related to the emplacement on land of the Franciscan rocks. The second one is a set of narrow, subvertical shear zones that are oriented parallel to the main Santa Ynez fault trace. These shear zones cross-cut the massive serpentinite blocks, as seen along Blue Canyon (B.C. on Fig. 2), and the orientation and sense of shear of these structures are consistent with the present-day sinistral movement of both the fault and the gouge zone that appears to localize deformation in the area (Fig. 4). We identify three main tectonic structures on the sub-horizontal plane that contains the slip vector (Fig. 5). Following the nomenclature of Passchier and Trouw (1996) these are: (Y) Y shear planes that tend to be parallel to the fault trace, (R) sigmoidal Riedel shear planes and (S) a schistosity. These observations are in accordance with previous ones on both naturally and experimentally deformed serpentinite gouges (Williams, 1979; Hoogerduijn Strating and Vissers, 1994; Reinen, 2000).

\section{Microstructures}

We have conducted microstructural observations on thin section from several rock samples, collected both outside and within the gouge zone.

Outside the gouge zone, the massive serpentinites show the mesh and bastite texture typical of hydrated oceanic peridotites (e.g. Wicks and Whittacker, 1977), and that is cross-cut several generations of serpentine veins. Serpentinization is almost complete and scarce relicts of primary minerals (olivine, pyroxene, spinel) are observed locally. The serpentinization of olivine is accompanied by the formation of iron-oxides heterogeneously distributed within the mesh texture. Spinels are often oxidized.

Because the gouge material is not cohesive, the samples have been impregnated with epoxy then sawed along the sub-horizontal plane containing the slip vector. All samples show similar structures in thin section, and therefore, we provide a detailed description of a representative thin section (rectangle on Fig. 5) showing both localized Y shear planes and distributed schistosity (Fig. 6) described at the outcrop scale. The schistosity appears as serpentine infill and is also locally outlined by oxide alignments that wrap around serpentinite clasts. Both the serpentinite clasts and the serpentine infill are made of very small crystals $(<$ $1 \mu \mathrm{m})$ that cannot be distinguished under a petrographic 




Fig. 2. Geological map of the studied region, north of Santa Barbara, around the 'Blue Canyon' (B.C.) (after Dibblee, 1986). The E-W Santa Ynez active fault crosscuts a serpentinite lens in this area. The following Figs. 3-5 are located on the map.

Table 1

Electron microprobe analyses of serpentinite clasts $(\mathrm{C})$ and the associated schistosity fibres $(\mathrm{S})$ within the gouge

\begin{tabular}{|c|c|c|c|c|c|c|c|c|c|c|c|}
\hline $\begin{array}{l}\text { Zone } 1 \text {, } \\
\text { nb meas. }\end{array}$ & $\begin{array}{l}\text { M C1a, } \\
n=2\end{array}$ & $\begin{array}{l}\text { M C1b, } \\
n=7\end{array}$ & $\begin{array}{l}\text { M C1c, } \\
n=3\end{array}$ & $\begin{array}{l}\text { M C1, } \\
n=a, b, c\end{array}$ & $\mathrm{M} \mathrm{S}, n=4$ & $\begin{array}{l}\text { Zone } 2, \\
\text { nb meas. }\end{array}$ & $\begin{array}{l}\text { M C2, } \\
n=15\end{array}$ & M S, $n=5$ & $\begin{array}{l}\text { Zone } 3 \text {, } \\
\mathrm{Nb} \text { meas. }\end{array}$ & $\begin{array}{l}\text { M C3, } \\
n=4\end{array}$ & $\mathrm{M} \mathrm{S}, n=4$ \\
\hline $\mathrm{F}$ & 0.0 & 0.0 & 0.0 & 0.0 & 0.1 & $\mathrm{~F}$ & 0.0 & 0.0 & $\mathrm{~F}$ & 0.0 & 0.1 \\
\hline $\mathrm{Na}_{2} \mathrm{O}$ & 0.1 & 0.0 & 0.0 & 0.0 & 0.1 & $\mathrm{Na}_{2} \mathrm{O}$ & 0.0 & 0.0 & $\mathrm{Na}_{2} \mathrm{O}$ & 0.0 & 0.0 \\
\hline $\mathrm{MgO}$ & 37.6 & 38.3 & 39.1 & 38.4 & 37.1 & $\mathrm{MgO}$ & 38.8 & 38.0 & $\mathrm{MgO}$ & 39.7 & 37.8 \\
\hline $\mathrm{SiO}_{2}$ & 41.3 & 40.9 & 41.1 & 41.1 & 39.7 & $\mathrm{SiO}_{2}$ & 39.5 & 40.3 & $\mathrm{SiO}_{2}$ & 38.3 & 38.2 \\
\hline $\mathrm{Al}_{2} \mathrm{O}_{3}$ & 1.5 & 1.8 & 1.9 & 1.7 & 2.0 & $\mathrm{Al}_{2} \mathrm{O}_{3}$ & 1.7 & 1.6 & $\mathrm{Al}_{2} \mathrm{O}_{3}$ & 1.7 & 1.6 \\
\hline $\mathrm{Cl}$ & 0.1 & 0.0 & 0.0 & 0.0 & 0.1 & $\mathrm{Cl}$ & 0.1 & 0.0 & $\mathrm{Cl}$ & 0.1 & 0.0 \\
\hline $\mathrm{K}_{2} \mathrm{O}$ & 0.1 & 0.1 & 0.0 & 0.1 & 0.1 & $\mathrm{~K}_{2} \mathrm{O}$ & 0.0 & 0.0 & $\mathrm{~K}_{2} \mathrm{O}$ & 0.0 & 0.0 \\
\hline $\mathrm{SO}_{3}$ & 0.1 & 0.1 & 0.1 & 0.1 & 0.1 & $\mathrm{SO}_{3}$ & 0.1 & 0.2 & $\mathrm{SO}_{3}$ & 0.2 & 0.2 \\
\hline $\mathrm{CaO}$ & 0.1 & 0.0 & 0.1 & 0.1 & 0.1 & $\mathrm{CaO}$ & 0.0 & 0.0 & $\mathrm{CaO}$ & 0.0 & 0.0 \\
\hline $\mathrm{Cr}_{2} \mathrm{O}_{3}$ & 0.0 & 0.1 & 0.1 & 0.1 & 0.1 & $\mathrm{Cr}_{2} \mathrm{O}_{3}$ & 0.1 & 0.3 & $\mathrm{Cr}_{2} \mathrm{O}_{3}$ & 0.1 & 0.1 \\
\hline $\mathrm{TiO}_{2}$ & 0.1 & 0.0 & 0.0 & 0.0 & 0.1 & $\mathrm{TiO}_{2}$ & 0.0 & 0.0 & $\mathrm{TiO}_{2}$ & 0.0 & 0.0 \\
\hline $\mathrm{MnO}$ & 0.1 & 0.1 & 0.1 & 0.1 & 0.1 & $\mathrm{MnO}$ & 0.1 & 0.2 & $\mathrm{MnO}$ & 0.1 & 0.1 \\
\hline $\mathrm{FeO}$ & 4.9 & 4.5 & 4.8 & 4.7 & 2.9 & $\mathrm{FeO}$ & 5.2 & 4.1 & $\mathrm{FeO}$ & 5.0 & 3.7 \\
\hline $\mathrm{NiO}$ & 0.1 & 0.0 & 0.1 & 0.1 & 0.3 & $\mathrm{NiO}$ & 0.5 & 0.4 & $\mathrm{NiO}$ & 0.4 & 0.5 \\
\hline Total & 86.1 & 86.0 & 87.4 & 86.5 & 83.0 & Total & 86.3 & 85.3 & Total & 85.7 & 82.3 \\
\hline
\end{tabular}

Three typical zones have been studied. The analyses within the schistosity have been made in the close vicinity to the clasts (few tens of micrometres) and three clasts have been analyses in zone $1(\mathrm{Ca}, \mathrm{Cb} ; \mathrm{Cc})$. Only the mean composition of clast from each zone (MCx) is given to compare with the mean composition of the neighbouring schistosity (MS). 'nb meas.' is the number of analysis used for calculating this mean. Results are in oxide weight percent. '-', measured as $0.0 \%$ wt; $\mathrm{C}$, rock clast; $\mathrm{S}$, schistosity; $\mathrm{M}$, mean value. 




Fig. 3. Picture of the contact between the upper Cretaceous sediment (NNE) and the serpentinite unit (SSW) in the Blue Canyon area (Fig. 2) and interpretation of the deformation structures at the outcrop scale. Major structures are: massive serpentinites blocks (circled), moderate dip schistosity (small dotted lines), subvertical shear zones with an associated schistosity (thick dashed lines).

microscope. The serpentine within the schistosity is easily recognised by a homogeneous transparent aspect under plane polarized light, a first order birefringence, and an undulose extinction under crossed polarized light. Fig. 7 shows a representative part of the gouge observed under SEM (backscattered electron mode) and characterized by serpentinite clasts embedded in an homogeneous schistose serpentine infill. A chemical contrast, marked by a difference in the colour of the serpentine minerals on the image, is systematically observed between the schistose serpentine (dark and very homogeneous) and the serpentinite clasts (lighter grey level).

In order to identify the origin of the chemical contrast between these two main gouge constituents, SEM element map (electron backscattered mode) and electron microprobe analyses of clasts and schistosity have been conducted on several representative zones. Neither localized concentrations nor significant contrasts in major element content 


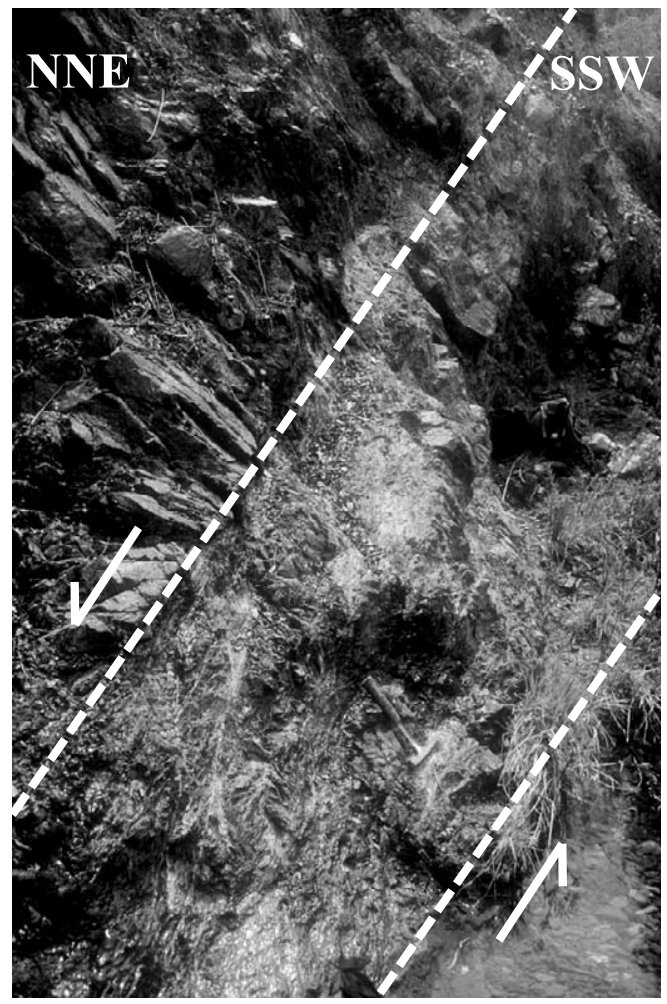

Fig. 4. Vertical shear zone parallel to the Santa Ynez fault trace within a massive block. The deformation is highly localized in a decimetric gouge zone. Hammer for scale.

are observed, with the exception of a slightly higher iron content in the clasts than in the matrix (Fig. 8).

To investigate the possible local iron transfer between clasts and schistosity, analyses by electron microprobe have been conducted on three zones of the thin section with a $5 \mu \mathrm{m}$ spot size (Table 1) in order to average the composition of several serpentine crystals in each constituent (example of zone 1 on Fig. 7). For all the zones, the concentrations of the detected elements, except Fe, are similar for the clasts and the schistosity. These results confirm that the slight chemical contrast observed by SEM is attributable to a small but significant difference in the iron content. The clasts are systematically richer in iron from 1.1 to $1.8 \%$ compared with the schistosity and the higher the mean iron content in the clast, the higher the mean iron content in the neighbouring schistosity.

\section{TEM observations}

Because of the very small grain size of serpentine crystals, it is necessary to use TEM in order to study the variability of the microtextures and nanostructures of these minerals and to relate them to the textures described in the previous section.

TEM observations have been performed with a JEOL 2000fx high-resolution transmission electron microscope at the CRMCN (CNRS, Marseille, France), with a $200 \mathrm{kV}$ accelerating voltage. A doubly polished thin section of the same rock chip of the gouge has been glued with Lakeside ${ }^{\circledR}$ resin to the glass substrate. A single-hole copper TEM grid was glued on an area selected for its ability for TEM observations, i.e. observation of both clasts and schistosity in a small area (Fig. 9). The specimen was extracted from the thin section by heating the resin after drilling around the grid. Prior to observation, specimens were thinned to perforation (Fig. 9) by ion-beam milling (Precision Ion Polishing System-Gatan 690) and carbon-coated.

Several light grey schistosity planes wrapping around small dark clasts are visible in the selected area (Fig. 9a) and sketched on Fig. 9b. The irregularity of the ion-beam milling process can lead to thicker zones that cannot be observed around the hole. The variation of the nature and microtextures of serpentine minerals and their location around the edge of the hole are illustrated on Figs. 10-14.

TEM observations show that different types of serpentine mineral coexist within the gouge: lizardite (platy structure), polygonal serpentine (fibrous type with a polygonized section) and chrysotile (fibrous cylindrical type) (see Wicks and O'Hanley (1988) for a review). These are all common serpentine phases in oceanic serpentinites (e.g. Viti and Mellini, 1998; Mével, 2003) and therefore may have been present prior to deformation. Antigorite, which is known as a 'higher grade' type of serpentine (Berman et al., 1986; Ulmer and Trommsdorff, 1995) that is typically found in subducted rocks, has not been observed in the studied sample. The microtextures vary within the sample and a clear distinction is made between the clasts and the schistosity planes. The clasts can be composed of variable proportions and arrangements of different serpentine types: e.g. lizardite with few chrysotile tubes in a vein clast (Fig. 11) or mostly polygonal serpentine plus short chrysotile tubes (Figs. 12 and 13). Figs. 12 and 13 show the contact (marked by the white arrow) between a clast composed by short serpentine fibres with no preferred orientation and a schistose zone characterized by long and perfectly parallel chrysotile tubes. The chrysotile tubes marking the schistosity are oblique with respect to the clast border. These observations identify the schistosity planes as made exclusively of long and parallel chrysotile tubes with a constant external diameter close to $20 \mathrm{~nm}$ (Figs. 12-14). In a single zone, the chrysotile tubes are perfectly parallel to each other but their mean orientation may vary from one zone to another (Fig. 10). The tubes are also locally folded or sheared (Fig. 14).

\section{The formation mechanism of schistosity: a creep process}

The previous observations suggest that schistosity is defined by long and parallel chrysotile tubes that are preferentially oriented within micrometre-wide zones. 


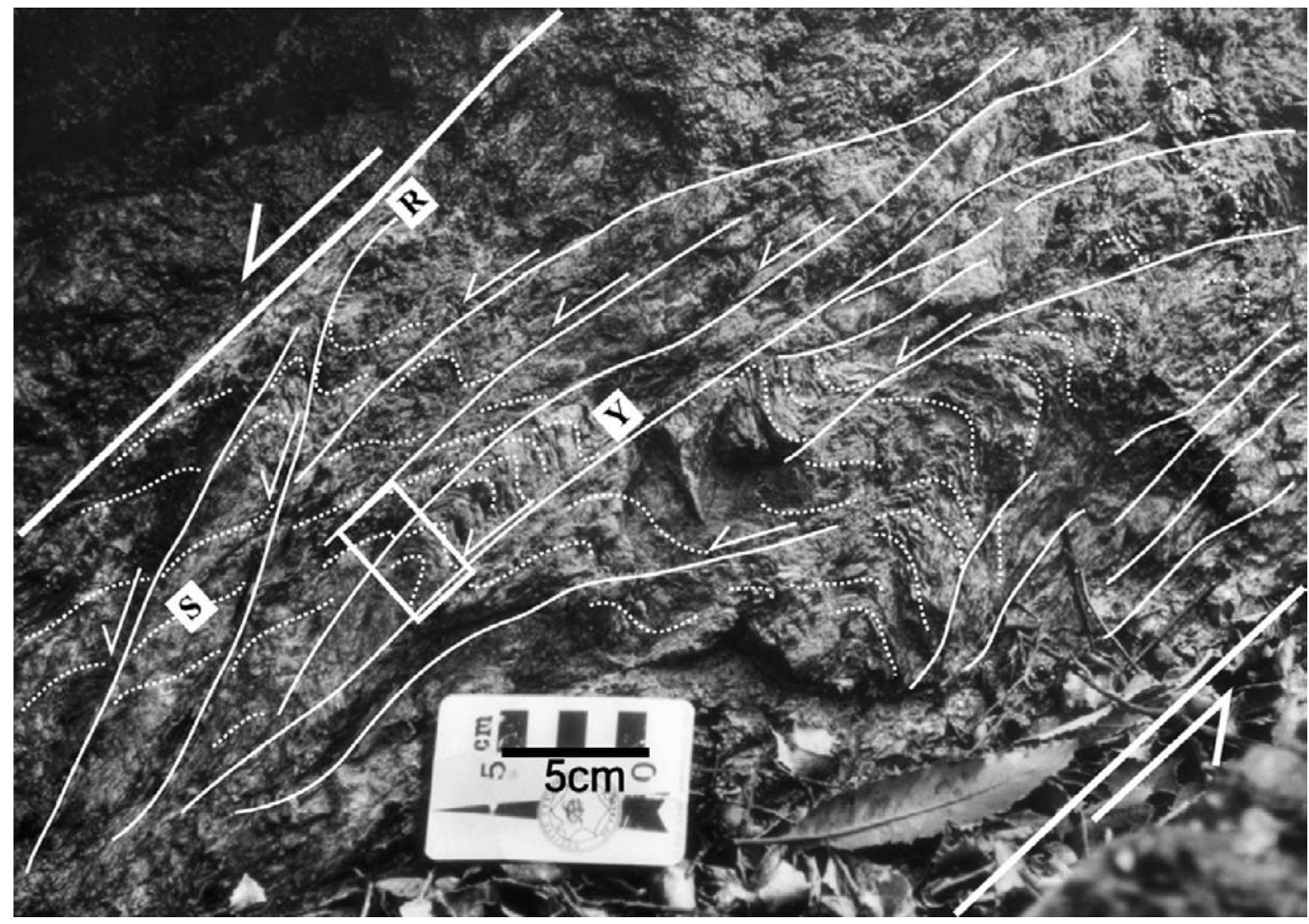

Fig. 5. Structure of the gouge zone observed in a sub-horizontal plane, parallel to the sinistral movement (lower left on Fig. 4). The location of the sample studied in detail at the micrometric scale is given by the white rectangle. Sigmoidal Riedel (R), local shear planes (Y), schistosity (S).

There are two hypotheses to explain the formation of such a texture within S-planes: (1) a rigid reorientation by shear of pre-existing chrysotile fibres, or (2) a synkinematic growth of fibres around clasts during shear. These two possibilities have already been discussed by Reinen (2000) to explain the formation of S-planes within experimental serpentinite gouges. The author concluded that passive rotation of preexisting grains better fitted the experimental conditions (room temperature, high strain rate, no additional fluids); this interpretation is similar to the conclusions of Chester and Logan (1987) for the development of foliation in natural clay-rich gouges. Nevertheless, Williams (1979) and Hoogerduijn Strating and Vissers (1994) hypothesized that synkinematic growth of chrysotile and lizardite occurred within the schistosity of an ancient natural gouge where antigorite was predominant. All these previously published
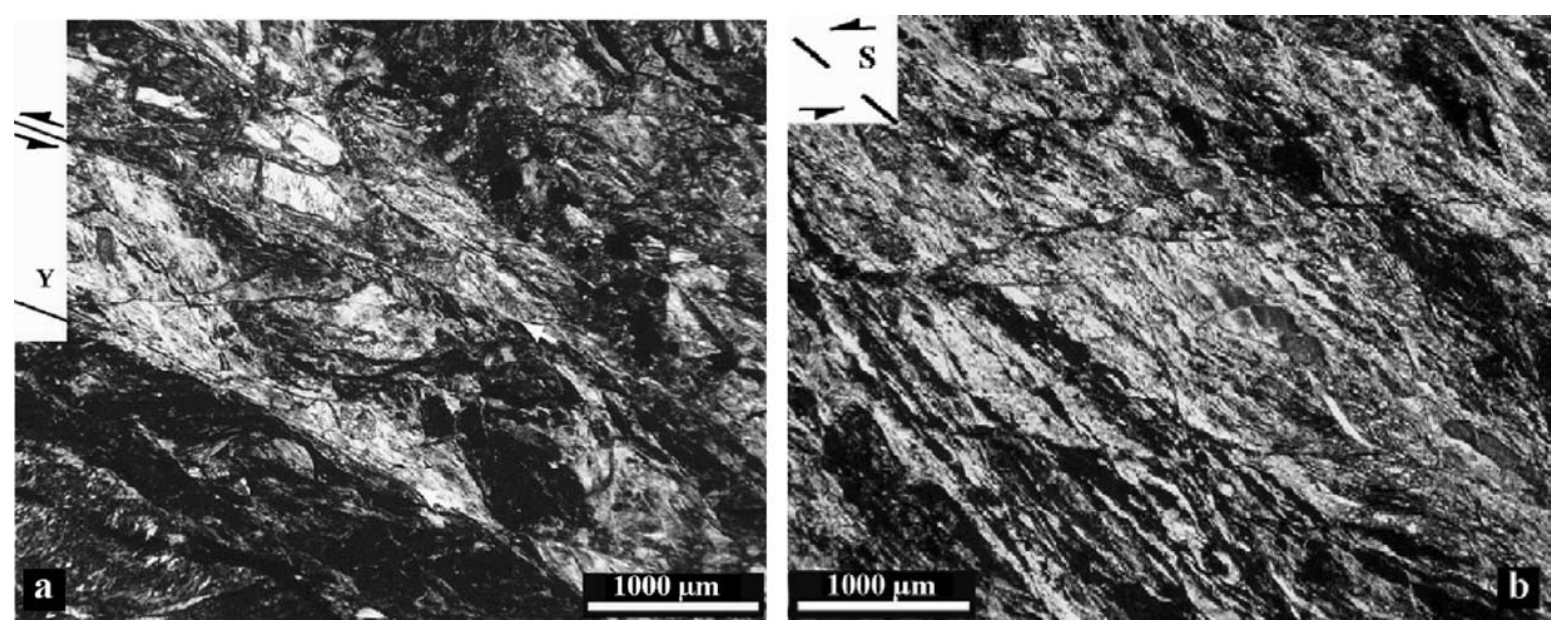

Fig. 6. Microstructures observed on a thin section of the gouge under crossed polarized light. (a) Localized shear planes (Y). (b) Schitosity (S) is defined by serpentine infill and oxides. 


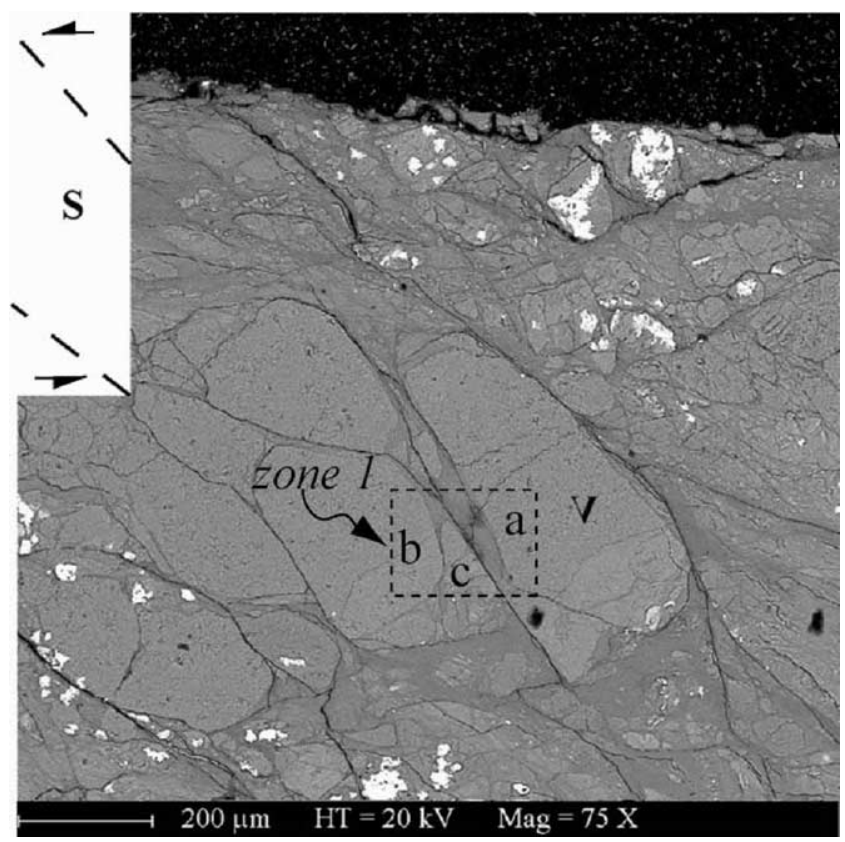

Fig. 7. SEM image of a characteristic zone of the gouge under backscattered electron mode. A contrast is observed between the massive serpentinite clasts (clearer) and the distributed schistosity (darker) that reflects a small difference in the mean atomic number of the elements that compose the minerals; the clasts are richer in heavier elements. The dashed rectangle locates one zone that has been analysed by electron microprobe (cf. Table 1). The letters are attributed to the clasts of this zone. observations have been made at the thin section scale, which does not allow the identification of the serpentine minerals and their fine-scale microstructures. Thus, the nature and the formation mechanism of schistosity in natural serpentinite gouges deformed at geological low strain rate are still uncertain, especially within shallow active faults.

Our TEM observations show that schistosity is exclusively related to well oriented chrysotile fibres (Fig. 11). Moreover, the chrysotile tubes observed in some clasts are short and irregularly oriented compared with those from the schistosity (Fig. 12). These observations are consistent with synkinematic growth of fibres around clasts and do not support the possibility of a concentration and reorientation of shorter, pre-existing fibres. This mechanism, which increases the abundance of chrysotile by creating newly formed crystals in the schistose zones, is also in accordance with field observations in low-temperature sheared serpentinites that indicate an increase of chrysotile abundance with increasing deformation degree (Page, 1968; Coleman and Keith, 1971; Wicks, 1984).

Different fibrous textures in veins or fringe structures have been described in various types of rocks and the detailed study of their internal microstructures can be interpreted in terms of formation mechanisms (see review in Passchier and Trouw (1996)). In our study, the fibrous texture observed in the schistosity is characterized by very long fibres of a constant width, which are not necessarily perpendicular to clast margins, and that do not show growth competition at the clast-schistosity limit. These
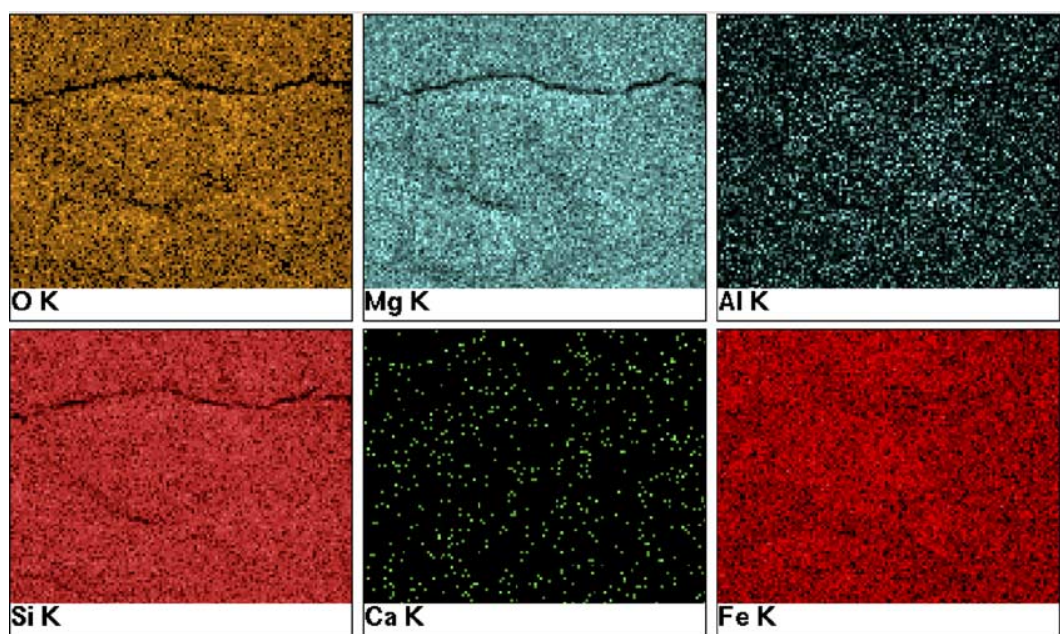

AlK
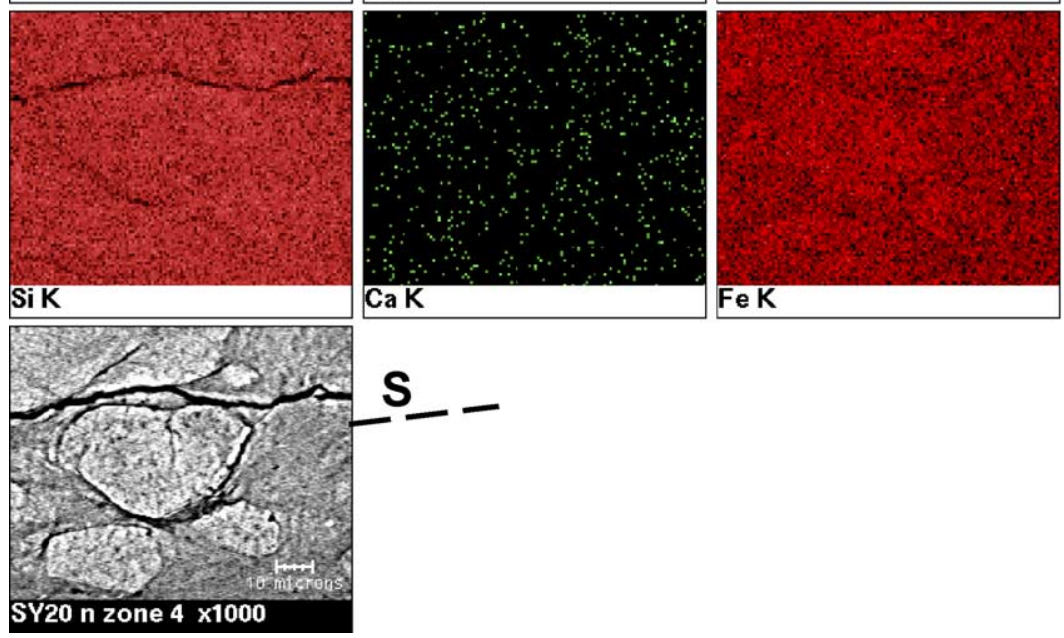

Fig. 8. EDX-SEM element maps of a clast and the neighbouring schistosity (indicated by 'S') within the gouge. Only a slightly higher iron content is observed in the clasts. 

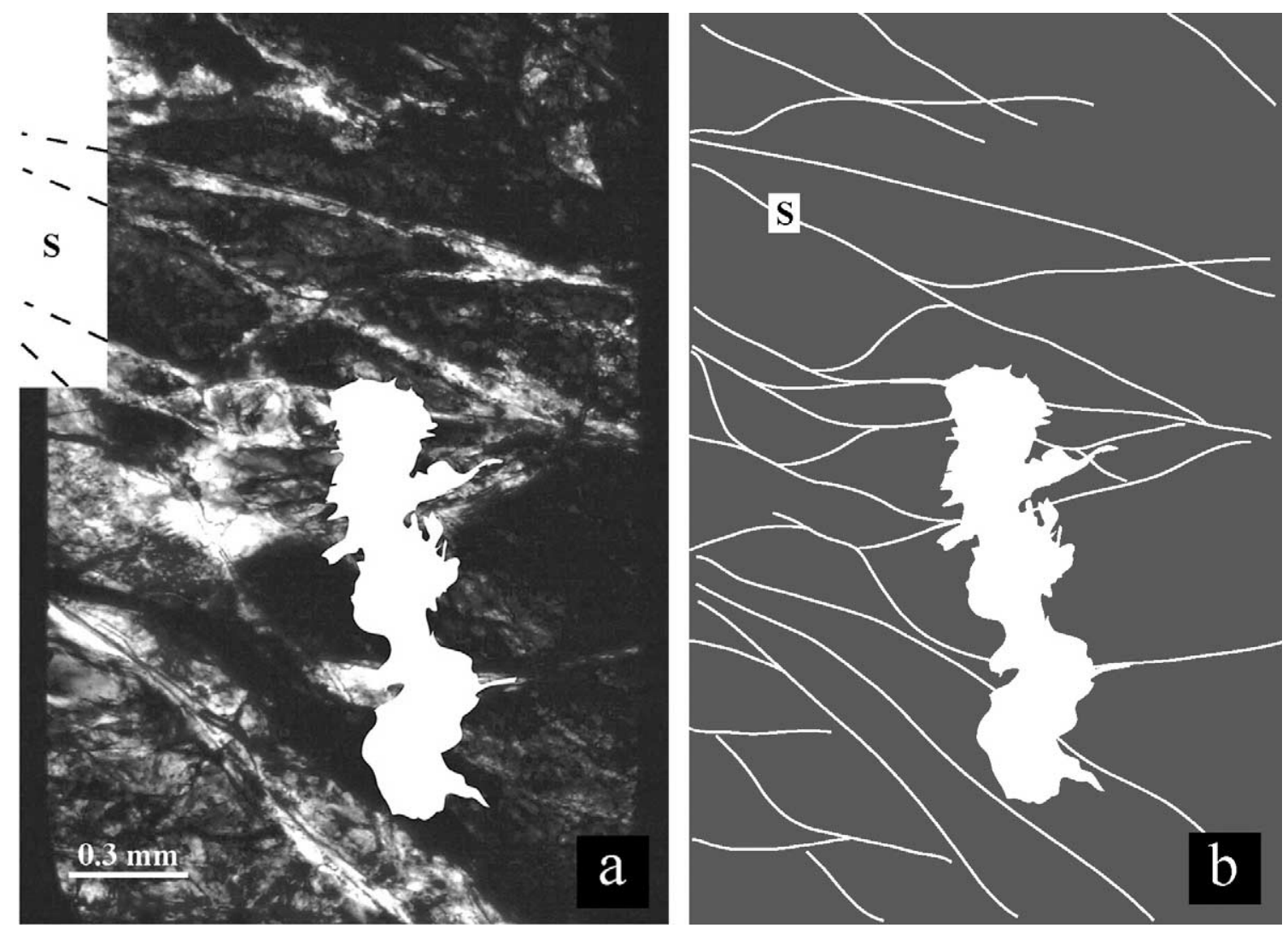

Fig. 9. Zone of the gouge thin section prepared for TEM observations. The milling of the sample leads to the formation of a hole in the middle of the selected section. The shape of the hole (white on the picture) is irregular. The observations were conducted in a narrow zone around the edge of the hole. (a) Image under crossed polarized light (S, schistosity). (b) Structural scheme of the zone showing the intersections of schistosity planes with the hole.

characteristics are similar to the displacement-controlled fibres associated with a formation process by dissolutiondiffusion-crystallization based on numerical modelling and experimental considerations (Fisher and Brantley, 1992; Bons and Jessell, 1997).

The formation mechanism of this type of texture requires a one-step nucleation at the first opening increment followed by a continuous crystal growth at the same rate, or higher, than the space opening process in dilation sites; otherwise crystals would grow in a fluid-filled open space and form blocky textures (Koehn et al., 2000; Hilgers et al., 2001). Experimental studies suggest that this fibrous texture can form without fracturing by an heterogeneous mass transfer and a localized precipitation in rock undergoing dissolution-precipitation creep (Bons and Jessell, 1997). Such a mechanism of mass transfer by diffusion has already been suggested in serpentinites to explain the filling of interstices leading to the formation of 'crack-seal' serpentine veins under hydrothermal conditions (Andreani et al., 2004). We thus conclude that fibres represent the precipitation site of a dissolution-diffusion-crystallization process, possibly enhanced by pressure-solution, which can effectively explain the observed schistosity in serpentinite gouges.

While the precipitation sites are readily identifiable by the microstructural observations, the location of dissolution sites and their nature are not. The zones of dissolution and precipitation of matter during pressure-solution in other rocks are usually demonstrated by a passive concentration of immobile elements in dissolution sites such as solution cleavage planes and precipitation of mobile elements in crystallization sites such as veins (Beach, 1977; Gratier, 1987). Chemical maps of the gouge, as in Fig. 8, do not show localized concentration of the heavy low-mobility elements such as $\mathrm{Cr}$ or $\mathrm{Fe}$ in planar structure. Some ironoxide alignments are locally observed but it is difficult to know if they result from a passive concentration by dissolution or from the initial heterogeneity of the serpentinite. Nevertheless, a chemical contrast due to the difference in the iron content has been noted between clasts and the anastomosing fibrous schistosity (Table 1). The slight increase in the iron content of schistosity with the increase in iron content of the adjacent clasts indicates that the composition of the chrysotile tubes forming the schistosity could be dependent on the mean composition of the adjacent clasts. This is in agreement with dissolution of matter from serpentinite clasts and short distance transfer of the elements that are needed for a synkinematic growth of the schistosity fibres. A diffusional mass transfer in an aqueous intergranular solution probably accommodates such a process and the dissolution of 

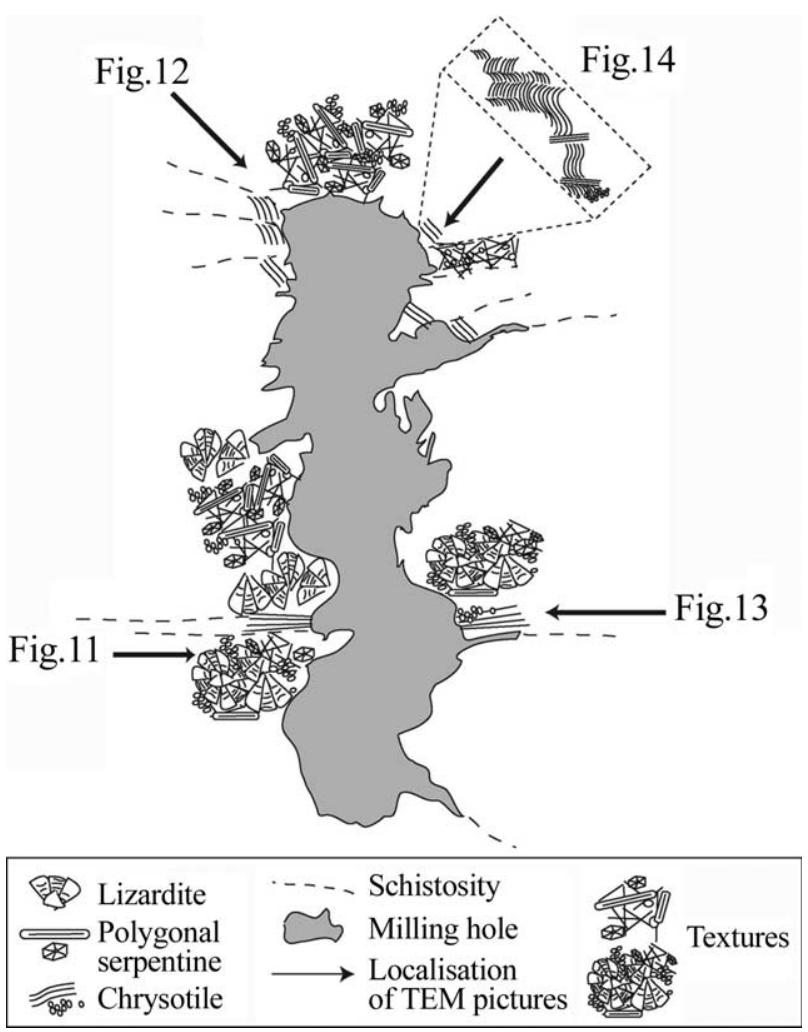

Fig. 10. Simplified illustration of the serpentine micro-textures observed under TEM around the hole. The location of the TEM images of Figs. 1114 are indicated with respect to the hole and the schistosity.

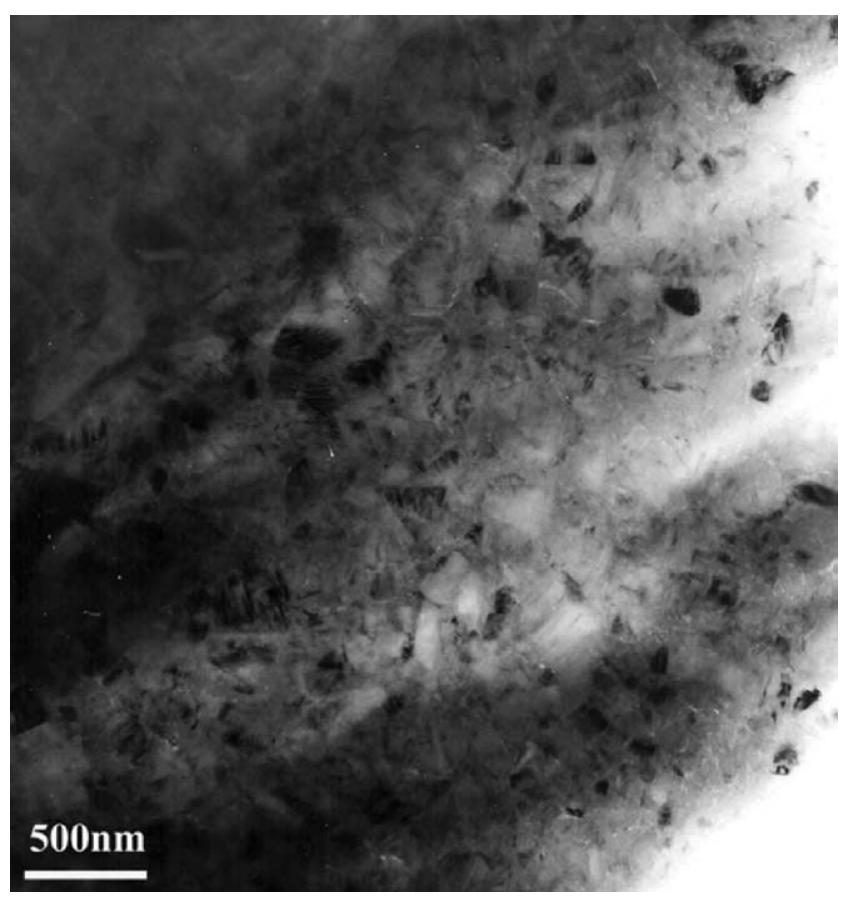

Fig. 11. TEM image showing the internal part of a clast of serpentinized peridotite included within the gouge. The variations in contrast are due to variations of crystallographic orientations under the electron beam. A majority of lizardite grains are observed with few fibrous serpentine inbetween.

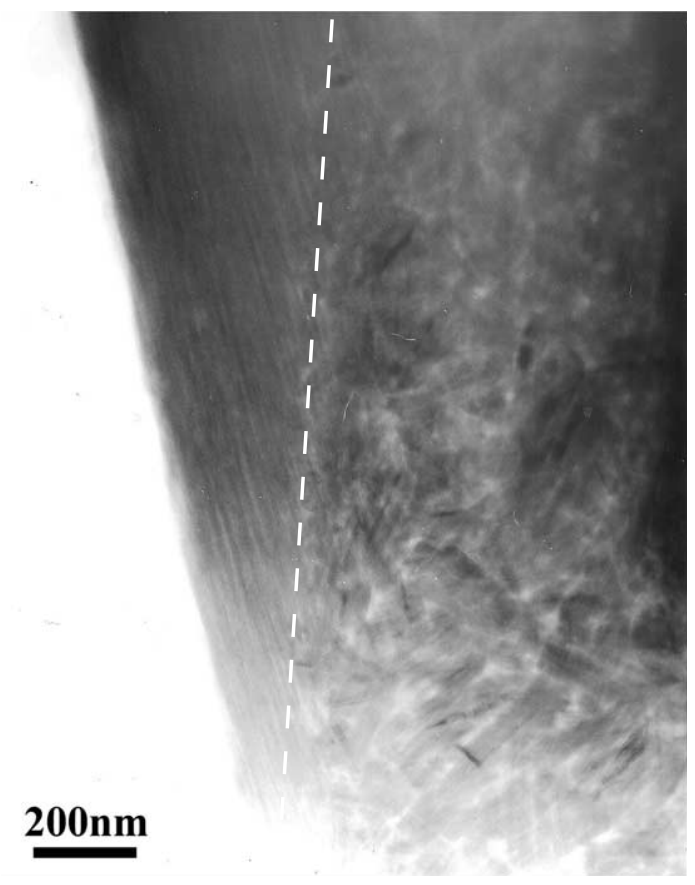

Fig. 12. TEM image showing the sharp limit (dotted line) between long chrysotile (Ctl) tubes and the margin of a clast made of short and misoriented tubes of polygonal serpentine (PS) and chrysotile (Ctl).

serpentine grains should be helped by their small size due to the normal capillary effect on solubility (Buckley, 1961).

We propose on Fig. 15 a sketch of this process based on the work of Cox and Etheridge (1989) who explain the development of grain-scale fibrous textures in deformed volcanic rocks by a coupled dilatancy and a mass transfer.



Fig. 13. TEM image of a 'pressure-shadow' of a clast included within the schistosity characterized by long and parallel chrysotile fibres (limit indicated by the dotted line). Note, the variable orientation of chrysotile and polygonal serpentine within the fragment. 


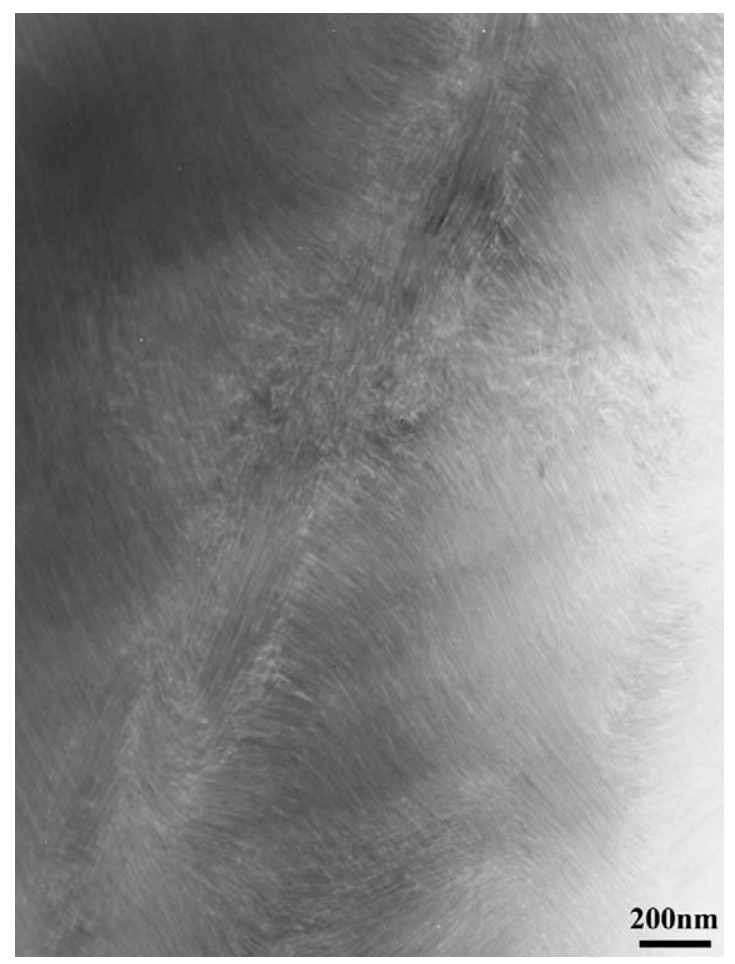

Fig. 14. TEM image of a fibrous zone composed of slightly curved and strongly oriented chrysotiles. A central narrow zone shows folded chrysotile fibres displaying a different and high-angle orientation.
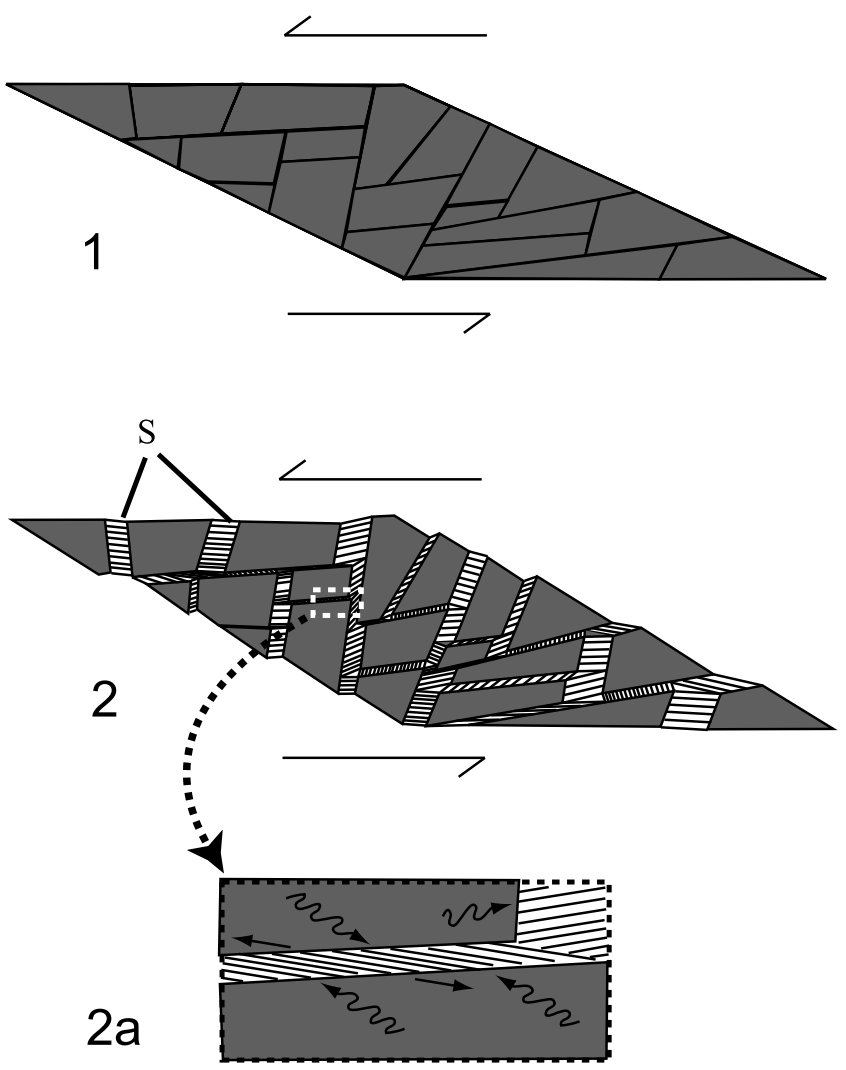

Fig. 15. Conceptual model proposed for the formation of the schistosity within the serpentinite gouge. See explanation in text.
The formation of schistosity accommodating a sinistral shearing can be summarized in two main steps (Fig. 15): (1) fracturing of the initial massive serpentinites occurs by a network of micrometre- to millimetre-scale shear and extension fractures; (2) fluids are present and the local heterogeneous stress around clasts within the gouge can induce physico-chemical processes, i.e. the progressive dissolution of the clasts. In the meantime, dilatant sites form between the dissolving clasts. The space is continuously filled by the crystallization of chrysotile fibres in response to dissolved matter coming from the neighbouring clast. Diffusion of solutes in the aqueous phase is an appropriate way to accommodate the slow and continuous transfer of elements over short distances, as required in this system. The growth direction of these long chrysotile fibres is guided by the local and instantaneous opening direction that can vary with the relative movements of clasts (Fig. 15-2a). Thus, they do not necessarily grow perpendicular to the clast edge (oblique on Fig. 12) and their mean orientation can vary from one zone to another in the gouge (Fig. 10). Clasts may also have a rotation component that can explain a change in fibres orientation during the growth (curved fibres on Fig. 14).

At the thin section scale (Fig. 6b), the extinction of the schistosity planes is the result of the mean orientation of these fibres and thus is undulose from one micro-zone to another. These arrangements of nano-tubes can be modified by local shearing or ongoing deformation that could deform the fibres or at least, reorientate them in restricted areas (Fig. 14).

The global kinetics of this creeping process of deformation is dependent on the kinetics of the three main steps, i.e. dissolution, diffusion and crystallization that would be more effective with increasing temperature. Thus, this process should have been more effective when the rocks were buried at depth than at surface conditions. The stability of serpentinite shows a small pressure dependence, while the temperature dependence is not well established, especially for lizardite and chrysotile. By compiling available data (Mével, 2003) a lower limit of $180^{\circ} \mathrm{C}$ or even lower (Barnes and O'Neil, 1967) and a upper limit of $250{ }^{\circ} \mathrm{C}$ (for stable reaction curves) up to $450{ }^{\circ} \mathrm{C}$ (for metastable reaction curves) can be proposed for chrysotile formation. Evans (2004) recently argued that within this range of temperature (surface $T$ to $450{ }^{\circ} \mathrm{C}$ ) chrysotile is a metastable phase whose occurrence is more determined by circumstances of growth rather than temperature and pressure. This temperature range for chrysotile formation corresponds to the upper $10-15 \mathrm{~km}$ of the crust (depending on the thermal gradient) and coincides with the thermal state of the seismogenic segments observed elsewhere in California (e.g. Sibson, 1982). Thus, this mode of deformation in serpentine can be proposed as an effective means to accommodate the creep observed in aseismic segments of the San Andreas Fault system, where serpentinites are present (Fig. 1). 
The pressure-solution strain rate will be limited by the slowest process (diffusional transfer or solid-fluid reactions). These parameters are still poorly constrained in the case of serpentinites. An experimental approach is now needed to determine them in order to integrate the ductile behaviour of serpentinites in the modelling of their deformation in different geological contexts.

\section{Conclusions}

This study shows that, at geological strain rates and in shallow environments, oceanic-type serpentinites (composed of lizardite and fibrous serpentines) deform in the semi-brittle field. Deformation is accommodated by coupling microfracturation to a slow creeping process involving dissolution-diffusion-crystallization. This latter mechanism of deformation has never been described in this type of rock. It explains the formation of schistosity in serpentinite fault gouge by a syntectonic growth of fibrous serpentine (chrysotile) around clasts. At the fault scale, this deformation mechanism of serpentinites leads to an aseismic behaviour of fault zones, which may explain seismological observations along the creeping segments of the San Andreas Fault system where serpentinites are present. These results have important consequences for seismic hazard estimation in continental environments such as California and this could also have major implications for the dynamics of the oceanic crust, particularly at subduction zones where serpentinites are abundant.

\section{Acknowledgements}

The authors want to thank S. Nitsche and D. Chaudanson for technical assistance, R.G. Coleman and M. Rymer for their help in locating serpentinite outcrops in central California, and L. Reinen and S. Cox for fruitful reviews that considerably improved the manuscript. This work has been supported by the Grenoble Observatory (OSUG) and IT02 program of the CRNS-INSU.

\section{References}

Allen, C.R., 1968. The tectonic environments of seismically active and inactive areas along the San Andreas fault system. In: Dickinson, W.R., Grantz, A. (Eds.), Conference on Geologic Problems of the San Andreas Faults System, Geological Science, vol. 11. Standford University Publishers, Standford, CA, pp. 70-82.

Andreani, M., Baronnet, A., Boullier, A.-M., Gratier, J.-P., 2004. A microstructural study of a 'crack-seal' type serpentine vein using SEM and TEM techniques. European Journal of Mineralogy 16, 585-595.

Atwater, T., 1989. Plate tectonic history of the northeast Pacific and western North America. In: Winterer, E.L., Hussong, D.M., Decker, R.W. (Eds.), The Eastern Pacific Ocean and Hawaii. Geology of North America. Geological Society of America, Boulder, CO, pp. 21-71.
Bailey, E.H., Blake, M.C.J., Jones, D.L., 1970. On-land Mesozoic oceanic crust in California Coast Ranges. Geological Survey Professional Paper 700-C, C70-C81.

Barnes, I., O’Neil, J.R., 1967. Geochemical evidence of present day serpentinization. Science 156, 830-832.

Beach, A., 1977. Vein arrays, hydraulic fractures and pressure solution structures in a deformed flysch sequence, S.W. England. Tectonophysics 40, 201-225.

Berman, R.G., Engi, M., Greenwood, H.J., Brown, T.H., 1986. Derivation of internally-consistent thermodynamic data by the technique of mathematical programming: a review with application to the system $\mathrm{MgO}-\mathrm{SiO}_{2}-\mathrm{H}_{2} \mathrm{O}$. Journal of Petrology 27, 1331-1364.

Bons, P., Jessell, M., 1997. Experimental simulation of the formation of fibrous veins by localised dissolution-precipitation creep. Mineralogical Magazine 61, 53-63.

Buckley, H.E., 1961. Crystal Growth. Chapter 1: Solution and Solubility, Solubility and Supersolubility. Wiley, pp. 1-42.

Bürgmann, R.D., Schmidt, D., Nadeau, R.M., d'Alessio, M., Fielding, E., Manaker, D., McEvilly, T.V., Murray, M.H., 2000. Earthquake potential along the northern Hayward fault, California. Science 289, 1178-1182.

Chester, F.M., Logan, J.M., 1987. Composite planar fabric of gouge from the Punchbowl Fault, California. Journal of Structural Geology $9(5 / 6)$, 621-634.

Coleman, R.G., 2000. Ultramafic Rock (serpentine) in California and Oregon. Standford Geological Survey.

Coleman, R.G., Keith, T.E., 1971. A chemical study of serpentinizationBurro Mountain, California. Journal of Petrology 12, 311-328.

Cox, S.F., Etheridge, M.A., 1989. Coupled grain-scale dilatancy and mass transfer during deformation at high fluid pressures: examples from Mount Lyell, Tasmania. Journal of Structural Geology 11, 147-162.

Dibblee, T.H., 1986. Geologic map of the Carpintera Quandrangle, Santa Barbara County, California. 1:24,000. U.S. Geological Survey.

Escartin, J., Hirth, G., Evans, B., 1997. Non-dilatant brittle deformation of serpentinites: implications for Mohr-Coulomb theory and the strength of faults. Journal of Geophysical Research 102 (B2), 2897-2913.

Evans, B.W., 2004. The serpentinite multisystem revisited: chrysotile is metastable. International Geology Review 46, 479-506.

Fisher, D.M., Brantley, S.L., 1992. Models of quartz overgrowth and vein formation: deformation and episodic fluid flow in an ancient subduction zone. Journal of Geophysical Research 97, 20043-20061.

Gratier, J.P., 1987. Pressure solution deposition creep and associated chemical differentiation in sedimentary rocks. In: Jones, M.E., Preston, R.M.F. (Eds.), Deformation Mechanisms in Sediments and Sedimentary Rocks. Journal of the Geological Society of London, Special Publications 29, pp. 25-38.

Hilgers, C., Koehn, D., Bons, P.D., Urai, J.L., 2001. Development of crystal morphology during unitaxial growth in a progressively widening vein: II. Numerical simulations of the evolution of antitaxial fibrous veins. Journal of Structural Geology 23 (6-7), 873-885.

Hoogerduijn Strating, E.H., Vissers, R.L.M., 1994. Structures in natural serpentinite gouges. Journal of Structural Geology 16 (9), 1205-1215.

Irwin, W.P., Barnes, I., 1975. Effect of geologic structure and metamorphic fluids on seismic behavior of the San Andreas fault system in central and northern California. Geology 3 (12), 713-716.

Koehn, D., Hilgers, C., Bons, P.D., Passchier, C.W., 2000. Numerical simulation of fibre growth in antitaxial strain fringes. Journal of Structural Geology 22 (9), 1311-1324.

Mevel, C., 2003. Serpentinization of abyssal peridotites at mid-ocean ridges. Comptes Rendus Géosciences 335, 825-852.

Moore, D.E., Lockner, D.A., Summers, R., Shengil, M.A., Byerlee, J.D., 1996. Strength of chrysotile-serpentinite gouge under hydrothermal conditions: can it explain a weak San Andreas fault? Geology 24, 10411044.

Moore, D.E., Lockner, D.A., Shengli, M., Summers, R., Byerlee, J.D., 1997. Strength of serpentinites gouges at elevated temperatures. Journal of Geophysical Research 102 (B7), 14787-14801. 
Page, B.M., 1972. Oceanic crust and mantle fragment in subduction complex near San Luis Obispo, California. Geological Society of America Bulletin 83, 957-972.

Page, B.M., Thompson, G.A., Coleman, R.G., 1998. Late Cenozoic tectonics of the central and southern Coast Ranges of California. Geological Society of America Bulletin 110 (7), 846-876.

Page, N.J., 1968. Serpentinization in a sheared serpentinite lens, Tiburon Peninsula, California. U.S. Geological Survey Professional Paper 600B, B21-B28.

Passchier, C.W., Trouw, R.A.J., 1996. Microtectonics. Springer, Berlin.

Raleigh, C.B., Paterson, M.S., 1965. Experimental deformation of serpentinite and its tectonic implications. Journal of Geophysical Research 70, 3965-3985.

Reinen, L.A., 2000. Seismic and aseismic slip indicators in serpentinite gouge. Geology 28, 135-138.

Reinen, L.A., Weeks, J.D., Tullis, T.E., 1991. The frictional behaviour of serpentinite; implications for aseismic creep on shallow crustal faults. Geophysical Research Letters 18, 1921-1924.

Schulz, S.S., Mavko, G.M., Burford, R.O., Stewart, W.D., 1982. Long-term fault creep observations in central California. Journal of Geophysical Research 87, 6977-6982.

Sibson, R.H., 1982. Fault zone models, heat flow, and the depth distribution of earthquakes in the continental crust of the United States. Bulletin of the Seismological Society of America 72, 151-163.

Ulmer, P., Trommsdorff, V., 1995. Serpentine stability to mantle depths and subduction-related magmatism. Science 268, 858-861.

Viti, C., Mellini, M., 1998. Mesh textures and bastites in the Elba retrograde serpentinites. European Journal of Mineralogy 10, 1341-1359.

Wicks, F.J., 1984. Deformation histories as recorded by serpentinites. II. Deformation during and after serpentinization. Canadian Mineralogist 22, 197-203.

Wicks, F.J., O'Hanley, D.S., 1988. Serpentine minerals: structures and petrology. In: Bailey, S. (Ed.), Hydrous Phyllosilicates. Reviews in Mineralogy, vol. 19. Mineralogical Society of America, pp. 91-167.

Wicks, F.J., Whittacker, E.J.W., 1977. Serpentine texture and serpentinization. Canadian Mineralogist 15, 459-488.

Williams, A.J., 1979. Foliation development in serpentinites, Glenrock, New South Wales. Tectonophysics 58, 81-95. 